Pak. J. Agri. Sci., Vol. 53(1), 51-57; 2016

ISSN (Print) 0552-9034, ISSN (Online) 2076-0906

DOI: 10.21162/PAKJAS/16.2606

http://www.pakjas.com.pk

\title{
DIFFERENTIAL RESPONSE OF TWO ACACIA SPECIES TO SALINITY AND WATER STRESS
}

\author{
Ghulam Abbas, ${ }^{1, *}$, Muhammad Saqib ${ }^{2}$ and Javaid Akhtar ${ }^{2}$ \\ ${ }^{1}$ Department of Environmental Sciences, COMSATS Institute of Information Technology, Vehari, Pakistan; \\ ${ }^{2}$ Institute of Soil and Environmental Sciences, University of Agriculture, Faisalabad, Pakistan. \\ *Corresponding author's e-mail: g.a92pk@gmail.com
}

\begin{abstract}
Salinity and drought are two important environmental problems responsible for the reduction of growth and yield of many plant species. The present study was conducted to evaluate the tolerance potential of A. nilotica and A. ampliceps against salinity and water shortage in the pots. Different salinity levels (control, 10, 20 and $30 \mathrm{dS} \mathrm{m}^{-1}$ ) were developed in the pots by adding calculated amount of $\mathrm{NaCl}$. Three months old nursery plants of both species were transplanted in these pots. After two weeks of transplantation, water stress was continuously applied till the end of the experiment. After four months, data regarding shoot and root growth, nodulation, chlorophyll and relative water contents were determined following standard methods. Ionic composition $\left(\mathrm{Na}^{+}, \mathrm{K}^{+}\right.$and $\left.\mathrm{Cl}^{-}\right)$of shoot and root was determined by wet digestion. The results demonstrated that $A$. ampliceps was more tolerant to salinity due to better ionic composition and physiological attributes but when salinity was combined with water stress; its tolerance potential was decreased. On the other hand, A. nilotica performed better under water stress and when salinity was combined with water stress.
\end{abstract}

Keywords: Salinity, water stress, acacia, nodulation, chlorophyll

\section{INTRODUCTION}

More than 6\% of the global land area and about $20 \%$ irrigated agricultural land is affected by salinity (Singh, 2009). Salinity reduces growth and yield of many plants (Saqib et al., 2013; Abbas et al., 2013). Osmotic effect is the main cause of reduction in growth of plants under salinity stress (Hu and Schmidhalter, 2005). In addition to ion toxicity, salinity is also responsible for nutritional disorders in plants (Saqib et al., 2006). Plants adapt to salinity by osmotic stress resistance, limiting the accumulation of $\mathrm{Na}^{+}$ and $\mathrm{Cl}^{-}$in their tissues (Munns and Tester, 2008) and maintaining higher $\mathrm{K}^{+}$concentration in the cells (Saqib et al., 2013).

Drought or water deficit is a serious abiotic stress that negatively affects the growth and productivity of crops (Zlatev and Lidon, 2012). Yield losses up to 50\% have been noticed for many crops due to water shortage (Wang et al., 2003). Drought affects plants in many ways and at various levels of their growth and development (Wentworth et al., 2006). As for salinity, water stress is also responsible for osmotic stress (Hu and Schmidhalter, 2005) and nutrient disorders in plants (Saqib et al., 2013). Moreover, it causes reduction in chlorophyll content which might be due to damage to chloroplasts caused by active oxygen species (Smirnoff, 1995). The leguminous plants have been observed to show low nodulation and nitrogen fixation capacity under drought stress (Pimratch et al., 2008). Drought resistant plants try to reduce water loss by increased stomatal resistance, increased water uptake through widespread root system (El-atta et al., 2012) and maintaining high relative water content (Zlatev, 2005; Gorai et al., 2010). Many acacia species are well adapted to saline conditions due to their better ionic balance in terms of $\mathrm{Na}^{+}$ and $\mathrm{K}^{+}$ions (Abbas et al., 2013; Marcar et al., 1991). Like other xerophytes, acacia has the capability to defy drought and survive under arid environments by conserving water (Ramoliya and Pandey, 2002). This is achieved either by reducing water loss or by escalating water absorption by various morphological and physiological adaptations (Aref and El-Juhany, 1999). Minimizing the exposed leaf surface area leads to limited water loss via transpiration from the plant. Reduction in leaf area is achieved by inhibiting leaf initiation (Ibrahim, 1995) or reducing leaf size (Ibrahim et al., 1998). Roots show a high degree of morphological plasticity that enables them to cope with shortage of water (El-atta et al., 2012). Production of thin and deep penetrating roots under water deficit conditions is considered an important mechanism for more water uptake (Ramoliya and Pandey, 2002)

A lot of research has been conducted with either water or salt stress separately, probably for the sake of convenience. In many places, salinity and drought occur together; therefore, the interactive studies considering both factors may give the true picture of the plant's performance in the natural field conditions (Ramoliya and Pandey, 2002; Saqib et al., 2013). The effect of higher salt concentration on plant growth in soils is basically through soil solution. Hence, it is 
supposed that soils having low moisture content may affect plant growth more than wet soils. Moreover, the occurrence of frequent droughts is almost a regular phenomenon in salt affected arid regions. Ultimately, effect of salts on the plant growth should be studied under both wet and dry soil conditions. The objective of this study was to evaluate the salinity and water stress tolerance potential of two acacia species, and how the water deficit alters the plant response to salt stress. The obtained information could be used for identification of plant species for the restoration of arid and salt affected ecosystems.

\section{MATERIALS AND METHODS}

Plant material and experimental techniques: A pot experiment was conducted for four months in the wire house of the Institute of Soil and Environmental Sciences, University of Agriculture Faisalabad, Pakistan, to investigate the effect of salinity and water stress on two acacia species. Faisalabad, Pakistan. Normal soil $\left(\mathrm{ECe}=2.31 \mathrm{dS} \mathrm{m}{ }^{-1}\right.$; sandy loam in texture) was collected from an agricultural field, passed through $2 \mathrm{~mm}$ sieve and filled in pots @ of $12 \mathrm{~kg}$ per pot. Calculated amount of $\mathrm{NaCl}$ was mixed in the soil of each pot to develop required (control, 10, 20 and $30 \mathrm{dS} \mathrm{m}^{-1}$ ) salinity levels. Three months old healthy nursery plants of both species were transplanted in these pots, keeping one plant in each pot. After the initial establishment of plants for two weeks, water stress treatment was started and continued till the end of the experiment. The plants under water stress were not irrigated for fifteen days at an alternate interval of fifteen days (i.e. fifteen days water stress and fifteen days normal irrigation). The plants without water stress were irrigated regularly so as to keep the soil moisture level to $70 \%$ of the soil water holding capacity.

Plant growth parameters: Data regarding growth parameters were taken before harvesting. Plant height was measured from base to the top of the stem in $\mathrm{cm}$ with meter rod. Stem diameter was measured with Vernier Calipers from 1 to $2 \mathrm{~cm}$ above the soil surface. After the harvest, data regarding root length, fresh and dry shoot and root weights were recorded.

Physiological attributes: Nodule number was counted manually and their dry weight was also determined. Chlorophyll content of the second top leaf was measured using SPAD-502 Chlorophyll meter. Relative water content was determined following the method of Sairam et al. (2002), according to which young leaf samples were weighed $(0.5 \mathrm{~g})$ as fresh weight $(\mathrm{FW})$ and immediately hydrated to full turgidity. After four hours, samples were taken out of distilled water and turgid leaves were quickly dried with filter paper to remove surface water and immediately weighed to obtain fully turgid weight (TW). These samples were oven dried at $65^{\circ} \mathrm{C}$ for 48 hours to determine dry weight (DW). Relative water contents were determined by the given formula:

$\mathrm{RWC}=[(\mathrm{FW}-\mathrm{DW}) /(\mathrm{TW}-\mathrm{DW})]$

Ionic composition: The roots and shoots were separately oven dried at $75^{\circ} \mathrm{C}$ for 48 hours. The dried and ground root and shoot samples were digested with $\mathrm{H}_{2} \mathrm{SO}_{4}$ and $\mathrm{H}_{2} \mathrm{O}_{2}$ following the method of Wolf (1982). After digestion, the volume was made $50 \mathrm{ml}$ with distilled water and used for ionic analysis. The ionic concentration for $\mathrm{Na}^{+}$and $\mathrm{K}^{+}$in plant samples was determined by Sherwood-410 flame photometer with the help of self-prepared standard solutions using reagent grade salts of $\mathrm{NaCl}$ and $\mathrm{KCl}$ respectively. Chloride was determined with Sherwood- 926 chloride analyzer. Standard procedures were applied to analyze the data using completely randomized (CRD) design with factorial arrangements (Steel et al., 1997) and the means were compared using least significant difference (LSD) test.

Table 1. Effect of salinity and water stress (WS) on growth parameters of acacia species.

\begin{tabular}{|c|c|c|c|c|c|c|c|c|}
\hline & Control & $10 \mathrm{dS} \mathrm{m} \mathrm{m}^{-1}$ & $20 \mathrm{dS} \mathrm{m}^{-1}$ & $30 \mathrm{dS} \mathrm{m}^{-1}$ & WS & $10 \mathrm{dS} \mathrm{m}^{-1}+\mathrm{WS}$ & $20 \mathrm{dS} \mathrm{m}^{-1}+\mathrm{WS}$ & $30 \mathrm{dS} \mathrm{m}^{-1}+\mathrm{WS}$ \\
\hline \multicolumn{9}{|c|}{ A. Plant height (cm) } \\
\hline A.ampliceps & $101 \mathrm{~cd}$ & 91 def & $80 \mathrm{gh}$ & 72 hi & $88 \mathrm{fg}$ & $81 \mathrm{fgh}$ & $65 \mathrm{ij}$ & $53 \mathrm{j}$ \\
\hline A. nilotica & $120 \mathrm{a}$ & $106 \mathrm{bc}$ & $90 \mathrm{efg}$ & $68 \mathrm{i}$ & $113 \mathrm{ab}$ & 99 cde & $85 \mathrm{fg}$ & $66 \mathrm{i}$ \\
\hline \multicolumn{9}{|c|}{ B. Stem diameter $(\mathrm{cm})$} \\
\hline A.ampliceps & $0.90 \mathrm{~b}$ & $0.81 \mathrm{~cd}$ & $0.75 \mathrm{de}$ & $0.61 \mathrm{gh}$ & 0.70 ef & $0.66 \mathrm{fg}$ & $0.60 \mathrm{gh}$ & $0.50 \mathrm{i}$ \\
\hline A. nilotica & $0.99 \mathrm{a}$ & $0.90 \mathrm{~b}$ & $0.78 \mathrm{~d}$ & $0.59 \mathrm{~h}$ & $0.87 \mathrm{bc}$ & $0.79 \mathrm{~d}$ & 0.70 ef & $0.56 \mathrm{~h}$ \\
\hline \multicolumn{9}{|c|}{ C. Root length (cm) } \\
\hline A.ampliceps & $68.5 \mathrm{~cd}$ & $62.2 \mathrm{def}$ & $55.2 \mathrm{fg}$ & $50.1 \mathrm{gh}$ & $61.4 \mathrm{ef}$ & $55.7 \mathrm{efg}$ & $45.9 \mathrm{~h}$ & $36.5 \mathrm{i}$ \\
\hline A. nilotica & $82.5 \mathrm{a}$ & $75.3 \mathrm{bc}$ & $62.7 \mathrm{de}$ & $47.8 \mathrm{~h}$ & $78.5 \mathrm{ab}$ & $70.0 \mathrm{c}$ & 60.6 ef & $46.0 \mathrm{~h}$ \\
\hline \multicolumn{9}{|c|}{ D. Shoot dry weight $\left(\right.$ g plant $\left.^{-1}\right)$} \\
\hline A.ampliceps & $14.3 \mathrm{a}$ & $12.8 \mathrm{~b}$ & $11.0 \mathrm{de}$ & $9.2 \mathrm{gh}$ & $11.0 \mathrm{de}$ & $10.3 \mathrm{f}$ & $8.6 \mathrm{~h}$ & $6.8 \mathrm{i}$ \\
\hline A. nilotica & $14.0 \mathrm{a}$ & $11.6 \mathrm{~cd}$ & $9.8 \mathrm{fg}$ & $7.3 \mathrm{i}$ & $12.1 \mathrm{bc}$ & $11.1 \mathrm{de}$ & $9.0 \mathrm{gh}$ & $7.0 \mathrm{i}$ \\
\hline \multicolumn{9}{|c|}{ E. Root dry weight (g plant $\left.{ }^{-1}\right)$} \\
\hline A.ampliceps & $6.04 \mathrm{a}$ & $5.5 \mathrm{bc}$ & $5.3 \mathrm{~cd}$ & $4.1 \mathrm{hi}$ & 4.8 efg & $4.50 \mathrm{gh}$ & $3.9 \mathrm{i}$ & $3.10 \mathrm{j}$ \\
\hline A. nilotica & $5.90 \mathrm{ab}$ & $5.1 \mathrm{de}$ & $4.6 \mathrm{fg}$ & $3.2 \mathrm{j}$ & $5.4 \mathrm{~cd}$ & $4.98 \mathrm{def}$ & $4.1 \mathrm{hi}$ & $3.13 \mathrm{j}$ \\
\hline
\end{tabular}

For each parameter values sharing a common letter are statistically similar according to LSD at P $<0.05$. 


\section{RESULTS}

Shoot and root growth: Salinity caused significant reduction in plant height and stem diameter of both the species, however when salinity was combined with water stress, more reduction was observed as compared to individual stress (Table 1). Effect of treatments, species and their interaction was significant for both these parameters at $\mathrm{P}<$ 0.05. A. nilotica produced significantly more plant height and stem diameter in all the treatments except at 20 and 30 $\mathrm{dS} \mathrm{m}^{-1}$. Salinity and water stress separately reduced shoot and root dry weight of both species, but when salinity was combined with water stress, the reduction was more pronounced as compared to either stress alone (Table 1). The species effect was non-significant for both shoot and root dry weight at $\mathrm{P}<0.05$. Comparison of both the species indicated that $A$. ampliceps produced more shoot and root dry weight under salinity stress. However, in $10 \mathrm{dS} \mathrm{m}^{-1}+$ water stress treatment, A. nilotica produced significantly more shoot and root dry weight than A. ampliceps. In rest of the treatments, both the species did not differ significantly from each other for both shoot and root dry weights. Root length was also reduced significantly due to salinity, water stress and their combination (Table 1). Effect of treatments, species and interaction of species with salinity was significant at $\mathrm{P}<0.05$. Comparison of both the species indicated that $A$. nilotica produced significantly more root length in all the treatments except in $30 \mathrm{dS} \mathrm{m}^{-1}$.

Physiological attributes: Nodulation, chlorophyll and relative water contents were decreased as a result of salinity

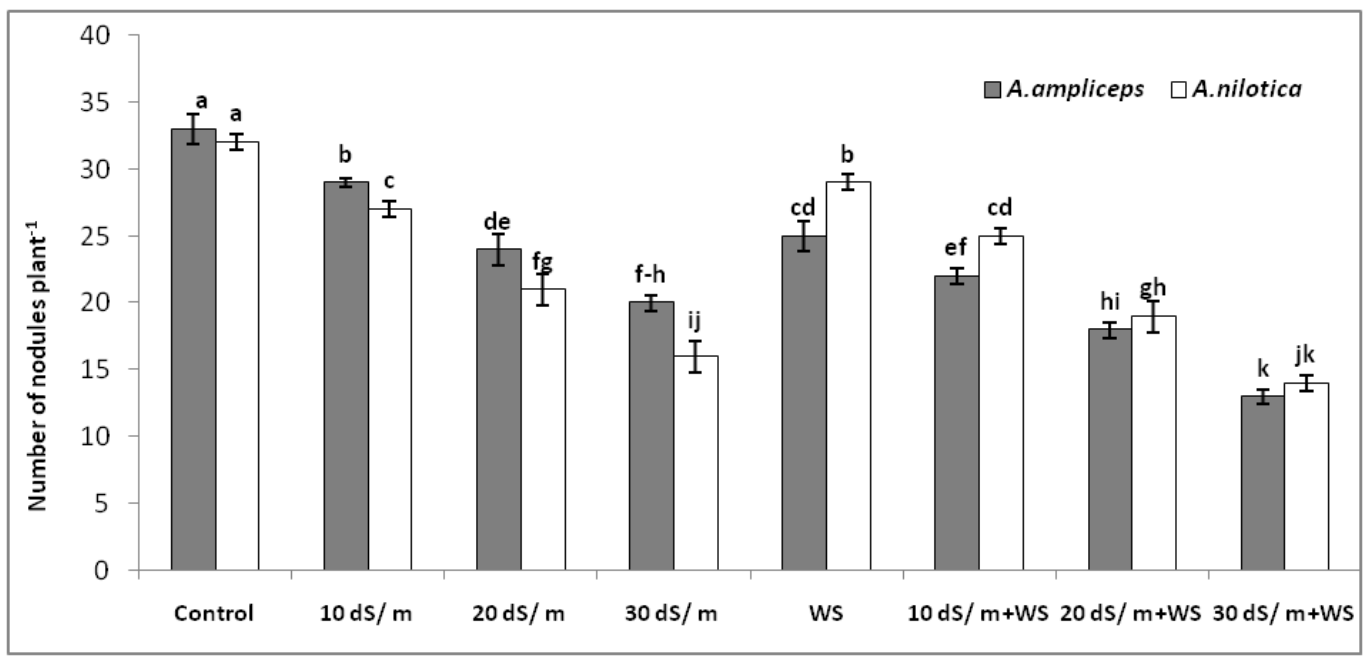

Figure 1. Effect of salinity and water stress (WS) on number of nodules of acacia species. For both species vertical bars having a common letter are statistically similar according to LSD at $\mathrm{P}<0.05$.

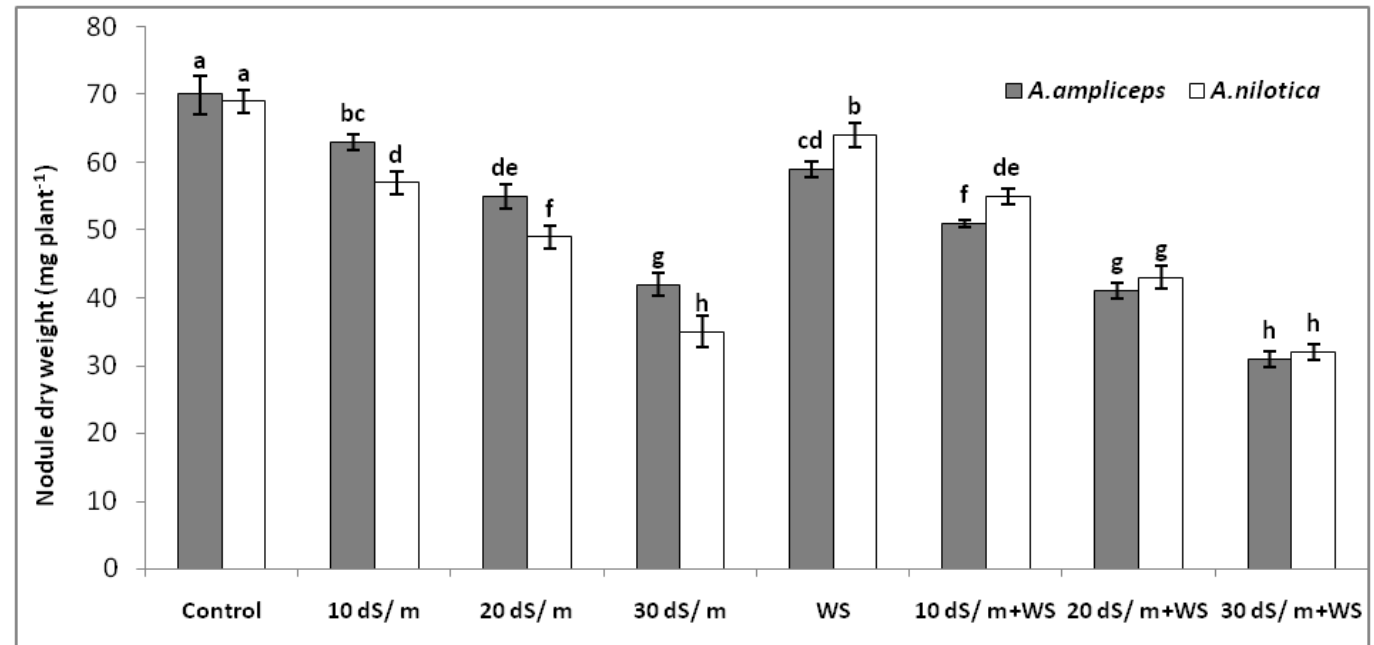

Figure 2. Effect of salinity and water stress (WS) on nodule dry weight of acacia species. For both species vertical bars having a common letter are statistically similar according to LSD at $\mathrm{P}<0.05$. 


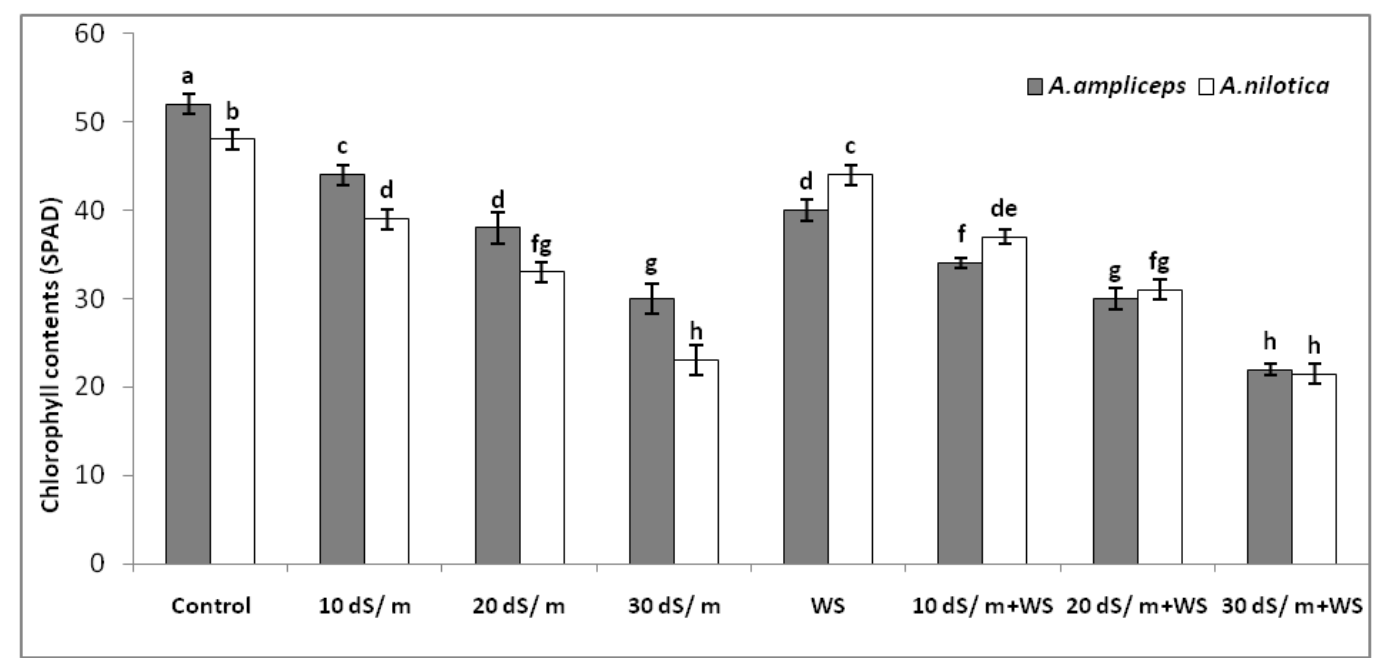

Figure 3. Effect of salinity and water stress (WS) on chlorophyll contents of acacia species. For both species vertical bars having a common letter are statistically similar according to LSD at $\mathrm{P}<0.05$.

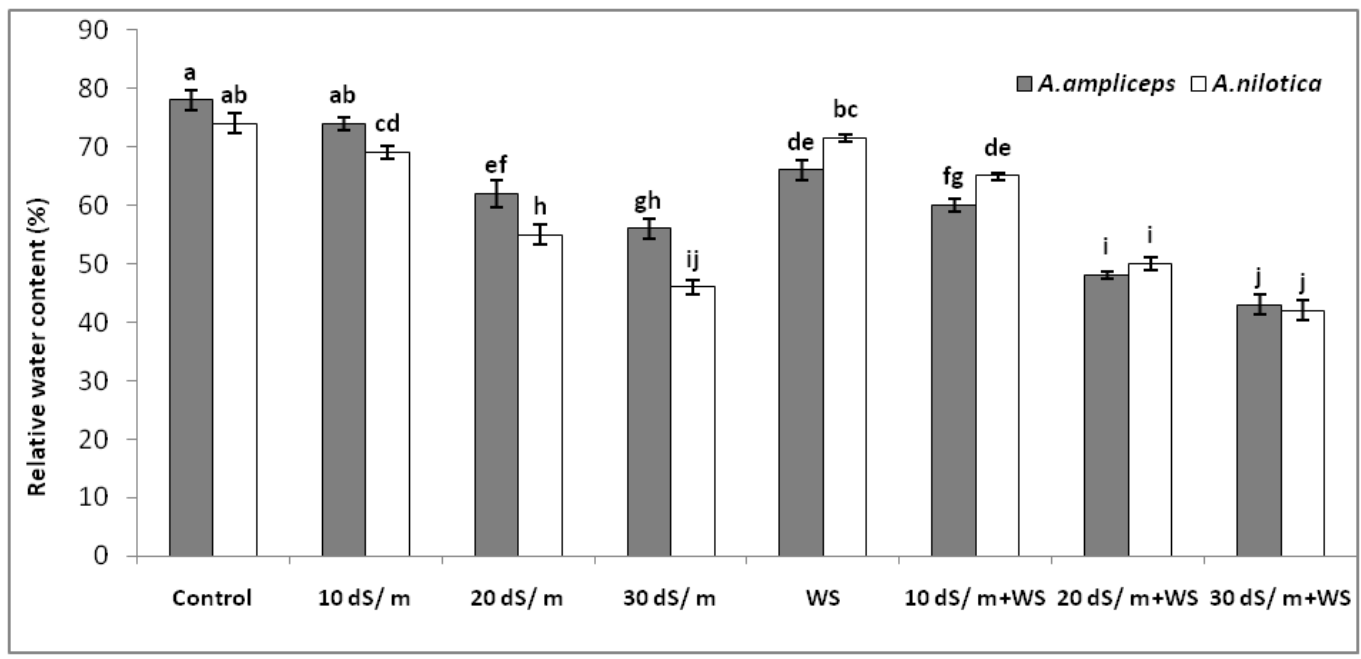

Figure 4. Effect of salinity and water stress (WS) on relative water content of acacia species. For both species vertical bars having a common letter are statistically similar according to LSD at $\mathrm{P}<0.05$.

and water stress, however their interactive effect was more detrimental than the either individual stress (Figs. 1-4). The species effect was non-significant for nodule dry weight at $\mathrm{P}$ $<0.05$. In case of chlorophyll and relative water contents, the main effects and the interaction of species with both treatments were significant at $\mathrm{P}<0.05$. The comparison of both the species indicated that $A$. ampliceps produced more values of these physiological attributes under salinity stress alone. However, under water stress alone, and its combination with $10 \mathrm{dS} \mathrm{m}^{-1}$ salinity, A. nilotica showed more values of all these parameters. When water stress was combined with 20 and $30 \mathrm{dS} \mathrm{m}^{-1}$ salinity levels, both the species did not differ significantly from each other regarding all these attributes.

Ionic composition: Salinity significantly increased the $\mathrm{Na}^{+}$ and $\mathrm{Cl}^{-}$concentration and caused reduction in $\mathrm{K}^{+}$ concentration in shoot and root of both species. Water stress in combination with salinity, further caused ionic imbalance in both species (Table 2). Effect of salinity, water stress and species was found significant at $\mathrm{P}<0.05$; however, the interaction of salinity and water stress was significant only in case of root for $\mathrm{Na}^{+}$and $\mathrm{K}^{+}$. Comparison of both species showed that $A$. ampliceps accumulated less $\mathrm{Na}^{+}$and $\mathrm{Cl}^{-}$and more $\mathrm{K}^{+}$as compared to A. nilotica in most of the treatments.

\section{DISCUSSION}

This study showed that effect of salt stress was modulated by water stress in acacia species. Increasing levels of salt in 
Salinity and water stress

Table 2. Effect of salinity and water stress (WS) on ionic composition of shoot (A) and $\operatorname{root}(\mathrm{B})$ of acacia species.

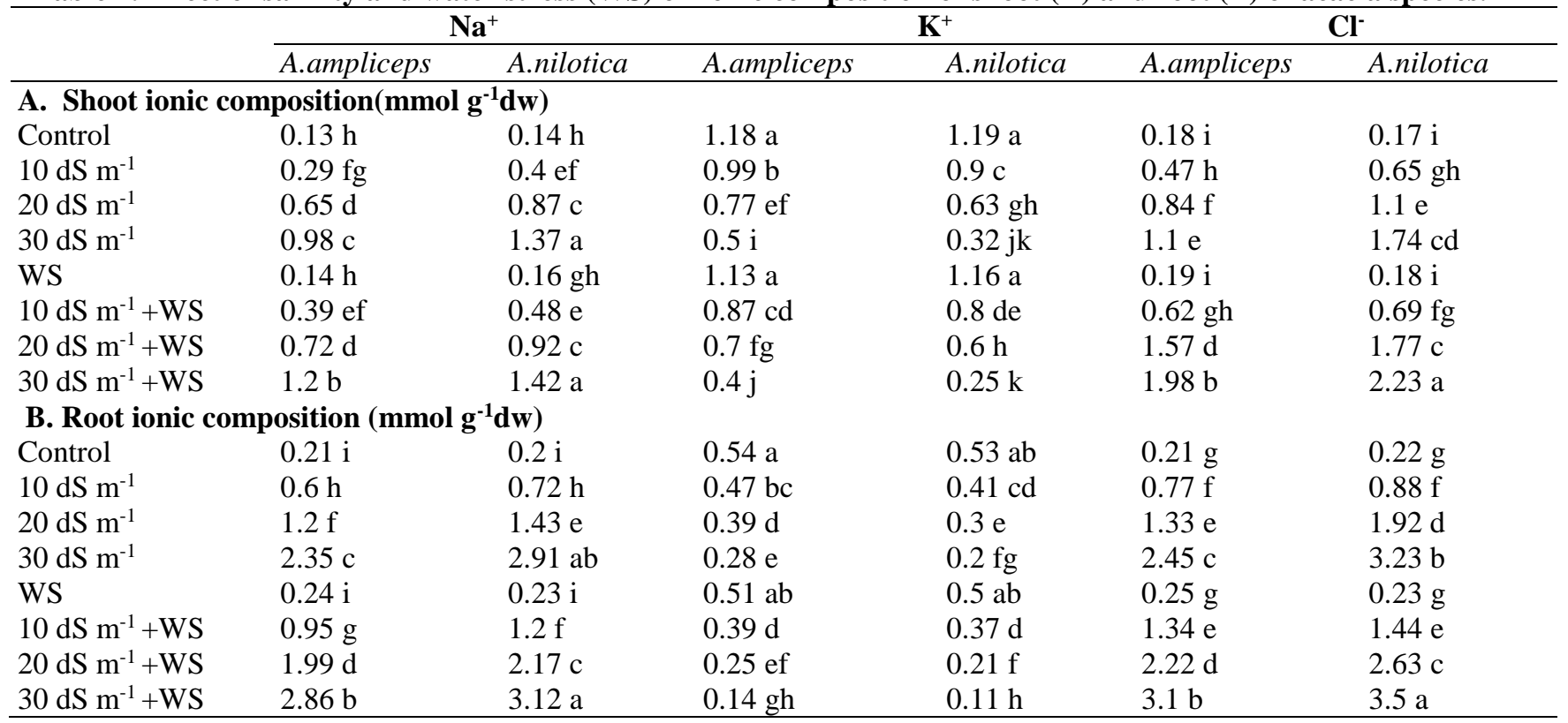

For each parameter values sharing a common letter are statistically similar according to LSD at P $<0.05$.

the growing medium caused significant reduction in plant height and stem diameter. However, when salinity was combined with water stress, both reduced these growth parameters in an additive manner. A. nilotica produced significantly more plant height and stem diameter in control and $10 \mathrm{dS} \mathrm{m}^{-1}$ salinity treatment. Increasing salt concentration at 20 and $30 \mathrm{dS} \mathrm{m}^{-1}$ salinity levels caused more reduction in these parameters in case of A. nilotica than $A$. ampliceps. On the other hand, under water stress alone and its combination with salinity, the reduction was more in the case of A. ampliceps. In this way the effect of salts was modulated by water deficit conditions at the same salinity levels. Reduction in these growth parameters under salinity (Mahmood et al., 2009), drought (El-atta et al., 2012) and their combination (EI-Juhany and Aref, 2005) had also been observed in the past.

Shoot and root dry weight was reduced due to salinity and water stress, but when salinity was combined with water stress, more reduction was noticed. Salinity alone caused more reduction in shoot and root dry weight in case of $A$. nilotica, which indicated that this species is less salt tolerant than A. ampliceps. However, when salinity was combined with water stress, more reduction was observed in case of $A$. ampliceps indicating relative sensitivity of this species to water stress. Reduction in shoot and root biomass in response to salinity (Abbas et al., 2013), water stress (El-atta et al., 2012) and their combination (Ramoliya and Pandey, 2002; EI-Juhany and Aref, 2005) was also observed in the past. Saqib et al. (2013) found that the yield and yield components of wheat were reduced under salinity and drought. Reduction in growth due to salinity could be the result of osmotic effect, ion toxicity and nutritional imbalance (Hu et al., 2006; Abbas et al., 2013). Likewise, water shortage is also responsible for osmotic stress ( $\mathrm{Hu}$ and Schmidhalter, 2005) and nutritional disorders in plants (Saqib et al., 2013). These harmful effects are operative at the cellular as well as higher levels of organization and have impact on all the features of plant metabolism. The osmotic effect caused by water deficit was more detrimental for $A$. ampliceps; whereas, the ion toxicity and imbalance caused by higher $\mathrm{Na}^{+}$and $\mathrm{Cl}^{-}$concentrations at higher salinity levels were more harmful for A. nilotica. At higher salinity levels i.e. 20 and $30 \mathrm{dS} \mathrm{m}^{-1}$ combined with water deficit, the defense mechanism of $A$. ampliceps against salts was less effective and resulted in severe reduction in shoot and root dry weights. Reduction in root weight was less as compared to shoot weight which indicated the morphological flexibility of root systems that facilitate acacia to survive under variable soil conditions. A. nilotica produced more root length than $A$. ampliceps. These results indicate that this species has an inclination for rapid root extension which confirms the better survival of this species in severe dry habitats (Pandey and Thakarar, 1997). Salinity and water deficit together caused more reduction in nodulation, chlorophyll and relative water contents in case of both species. Salinity alone was more detrimental for A. nilotica and water stress was more harmful for $A$. ampliceps. Reduction in nodulation of leguminous plants had been observed under drought (Pimratch et al., 2008) as well as salinity stress (Al-shaharani and Shetta, 2011). Likewise, 
water deficit caused reduction in chlorophyll contents of Acacia tortilis as observed by Kebbas et al. (2015). This reduction is mainly endorsed to damage to chloroplasts caused by reactive oxygen species (Smirnoff, 1995), which are produced under both salinity and water stress along with toxic effects of ions. According to Ramoliya and Pandey (2002) high relative water content of leaves is an adaptation to xeric habitats. The higher values of relative water contents under drought were noticed in drought tolerant bean (Zlatev, 2005) and in Astragalus gombiformis Pom. and Edicago sativa L. (Gorai et al., 2010). Our results are in confirmation with these observations as we also found that $A$. nilotica which is relatively drought tolerant species showed more relative water content than $A$. ampliceps.

Salinity significantly increased $\mathrm{Na}^{+}$and $\mathrm{Cl}^{-}$and decreased $\mathrm{K}^{+}$ concentration in shoot and root of both the species. Water stress in combination with salinity, further deteriorated this ionic imbalance. Such ionic imbalance in response to salinity (Abbas et al., 2013; Khalil et al., 2012) and under combination of salinity and drought (Saqib et al., 2013) had also been previously noticed. A. ampliceps accumulated less $\mathrm{Na}^{+}$and $\mathrm{Cl}^{-}$as compared to A. nilotica in both shoot and root. Comparison of shoot and root showed that concentration of $\mathrm{Na}^{+}$and $\mathrm{Cl}^{-}$ions was more in root than shoot. This type of ion accumulation is a salt tolerant behavior known as ion exclusion and it is positively related with salt tolerance of various plant species (Saqib et al., 2005; Munns and Tester, 2008). The higher uptake of these ions caused more reduction in growth due to which $A$. nilotica showed less tolerance to salinity than A. ampliceps. Potassium $\left(\mathrm{K}^{+}\right)$has a key role in salt tolerance and uptake of $\mathrm{K}^{+}$is decreased under both salinity and water stress (Saqib et al., 2013). Reduction of $\mathrm{K}^{+}$concentration in both parts indicated that $\mathrm{Na}^{+}$repressed the uptake of $\mathrm{K}^{+}$. More uptake of $\mathrm{Na}^{+}$in case of $A$. nilotica indicated that ion exclusion was poorly operative in this species, so it had less $\mathrm{K}^{+}$ concentration as compared to A. ampliceps.

Conclusion: This study explored the tolerance potential of two acacia species for two very important abiotic stresses i.e. salinity and drought. We observed that A. ampliceps was more tolerant to salinity stress than A. nilotica. On the other hand, A. nilotica performed better under water stress alone as well as when it was combined with salinity. Therefore, it is recommended that under the combined stress of salinity and water shortage, A. nilotica should be grown for the rehabilitation of marginal lands.

\section{REFERENCES}

Abbas, G., M. Saqib, J. Akhtar and S.M.A. Basra. 2013. Salinity tolerance potential of two acacia species at early seedling stage. Pak. J. Agri. Sci. 50:683-688.
Al-shaharani and N.D. Shetta. 2011. Evaluation of growth, nodulation and nitrogen fixation of two acacia species under salt stress. World App. Sci. J. 13:256-265.

Aref, I.M. and L.I. El-Juhany. 1999. Effects of water deficit on the growth of Acacia asak (forssk.), A. tortilis (forssk.) and A. gerrardii (benth) ssp. negevensis (zoh.). J. Agric. Sci. Mansura Univ. 24:5627-5636.

EI-Juhany, L.I. and I.M. Aref. 2005. Interactive effects of low water supply and high salt concentration on the growth and dry matter partitioning of Conocarpus erectus seedlings. Saudi J. Biol. Sci. 12 :147-157.

El-atta, H.A., I.M. Aref, A.I. Ahmed and P.R. Khan. 2012. Morphological and anatomical response of Acacia ehrenbergiana Hayne and Acacia tortilis (Forssk) Haynes subspp. raddiana seedlings to induced water stress. Afr. J. Biotechnol. 11:10188-10199.

Gorai, M., A. Hachef and M. Neffati. 2010. Differential responses in growth and water relationship of Medicago sativa (L.) cv. Gabes and Astragalus gombiformis (Pom.) underwater-limited conditions. Emir. J. Food Agric. 22:1-12.

$\mathrm{Hu}$, Y. and U. Schmidhalter. 2005. Drought and salinity: a comparison of their effects on mineral nutrition of plants. J. Plant Nutr. Soil Sci. 168:541-549.

$\mathrm{Hu}$, Y., Z. Burucs and U. Schmidhalter. 2006. Short-term effect of drought and salinity on growth and mineral elements in wheat seedlings. J. Plant Nutr. 29:22272243.

Ibrahim, L. 1995. Effects of nitrogen supply, water stress and interaction between water and nitrogen on assimilate partitioning in poplar. $\mathrm{Ph}$. D thesis, University of Aberdeen, UK.

Ibrahim, L., M.F. Proe, and A.D. Cameron. 1998. Interactive effects of nitrogen and water availability on gas exchange and whole plant carbon allocation in poplar. Tree Physiol. 18:481-487.

Kebbas, S., S. Lutts and F. Aid. 2015. Effect of drought stress on the photosynthesis of Acacia tortilis subsp. raddiana at the young seedling stage. Photosynthetica. 53:288-298.

Khalil, A., M. Saqib, J. Akhtar and R. Ahmad. 2012. Evaluation and characterization of genetic variation in maize (Zea maysL.) for salinity tolerance. Pak. J. Agri. Sci. 49:521-526.

Mahmood, K., G. Sarwar, N. Hussain, H. Schmeisk and S. Muhammad. 2009. Effect of soil salinity and sodicity on growth parameters of Acacia ampliceps. Pak. J. Agric. Res. 22:132-139.

Marcar, N.E., P. Dart and C. Sweeney. 1991. Effect of rootzone salinity on growth and chemical composition of $A$. ampliceps B. R. Maslin, A. auriculiformis, A. cunn. ex Benth. and $A$. mangium Willd. at two nitrogen levels. New Phyt. 119:567-573. 
Munns, R. and M. Tester. 2008. Mechanisms of salinity tolerance. Ann. Rev. Plant Biol. 59:651-681.

Pandey, A.N. and N.K. Thakarar. 1997. Effect of chloride salinity on survival and growth of Prosopis chilensis seedlings. Trop. Ecol. 38:145-148.

Pimratch, S., S. Jogloy, N. Vorasoot, B. Toomsan, A. Patanothai, and C.C. Holbrook. 2008. Relationship between biomass production and nitrogen fixation under drought-stress conditions in peanut genotypes with different levels of drought resistance. J. Agron. Crop Sci. 194:15-25.

Ramoliya, P.J. and A.N. Pandey. 2002. Effect of salinization of soil on emergence, growth and survival of seedlings of Acacia nilotica. Bot. Comp. 26:105-119.

Sairam, R.K., K.V. Rao and G.C. Srivastava. 2002. Differential response of wheat genotypes to long term salinity stress in relation to oxidative stress, antioxidant activity and osmolyte concentration. Plant Sci. 163:1037-1046.

Saqib, M., J. Akhtar and R.H. Qureshi. 2005. $\mathrm{Na}^{+}$exclusion and salt resistance of wheat (Triticum aestivum L.) in saline-waterlogged conditions are improved by the development of adventitious nodal roots and cortical root aerenchyma. Plant Sci. 169:125-130.

Saqib, M., C. Zorb and S. Schubert. 2006. Salt-resistant and sensitive wheat genotypes do not show very different biochemical reaction at the level of proteins in the first phase of their response to $\mathrm{NaCl}$ salinity. J. Plant Nutr. Soil Sci. 169:542-548.

Saqib, M., J. Akhtar, G. Abbas and M. Nasim. 2013. Salinity and drought interaction in wheat (Triticum aestivum L.) is affected by the genotype and plant growth stage. Acta Physiol. Plant. 35:2761-2768.

Singh, G. 2009. Salinity related desertification and management strategies: Indian experience. Land Degrad. Develop. 20:367-385.

Smirnoff, N. 1995. Antioxidant systems and plant response to the environment. In: V. Smirnoff (ed.) Environment and plant metabolism: Flexibility and acclimation, BIOS Scientific Publishers, Oxford, UK.

Steel, R.G.D., J.H. Torrie and D.A. Dickey. 1997. Principles and Procedures of Statistics: A Biometrical Approach. 3rd ed. McGraw Hill Co., New York, USA.

Wang, W., B. Vinocur, and A. Altman. 2003. Plant responses to drought, salinity and extreme temperatures: towards genetic engineering for stress tolerance. Planta. 218:1-14.

Wentworth, M., M.H. Murchie, J.E. Gray, D. Villegas, C. Pastenes, M. Pinto and P. Horton. 2006. Differential adaptation of two varieties of common bean to abiotic stress. II. Acclimation of photosynthesis. J. Exp. Bot. 57:699-709.

Wolf, B. 1982. A comprehensive system of leaf analysis and its use for diagnosis crop nutrient status. Comm. Soil Sci. Plant Anal. 13:1035-1059.

Zlatev, Z. 2005. Effects of water stress on leaf water relations of young bean plants. J. Cent. Eur. Agric. 6:514.

Zlatev, Z. and F.C. Lidon. 2012. An overview on drought induced changes in plant growth, water relations and photosynthesis. J. Food Agric. 24:57-72. 